\title{
Možnosti využití tréninku mindfulness v profesionální praxi sociální práce ${ }^{1}$ Miroslav Kappl
}

\begin{abstract}
Abstrakt:
Příspěvek se zabývá možnostmi využití tréninku mindfulness v praxi případové sociální práce. Trénink mindfulness je $v$ tomto kontextu nahlížen jako metoda posilování některých důležitých kompetencí klientů, s jejichž pomocí dokážou realizovat potřebné změny ve svých životech. Text příspěvku ve stručnosti shrnuje historii užívání této metody a popisuje některé výsledky současných neurovědních výzkumů věnovaných této problematice. Dále se věnuje možnostem aplikace tréninku mindfulness v oboru sociální práce s vybranými skupinami klientů. $V$ závěru textu kriticky upozorňuje na některé sporné aspekty užívání této metody v práci s klienty.
\end{abstract}

Klíčová slova: sociální práce, metody sociální práce, trénink mindfulness, meditace

\section{Úvod}

S nástupem diskursu neurověd do širšího okruhu pomáhajících profesí, který přinesl další impuls pro rozvoj jejich metodik práce s klienty, se v oboru sociální práce pomalu a jistě dostává uznání i fenoménu tréninku mindfulness. ${ }^{2}$ I když je tato metoda známa profesní veřejnosti již několik desetiletí díky autorům, kteří se ve své praxi opírali o některé východní filozofické koncepty ${ }^{3}$, byly to až výsledky neurovědních výzkumů mozku, které potvrdily a zpopularizovaly efektivní účinky tohoto cvičení, které pod názvem „meditace“ bylo praktikováno v nejrůznějších kulturních okruzích již od starověku, pravděpodobně však ještě dřive. ${ }^{5}$

V okamžiku, kdy se diskurs neurověd začal soustřed’ovat na téma „pozornosti“, která byla rozpoznána jako důležitá komponenta každého procesu učení a rozhodování, byl identifikován význam meditace jakožto nástroje, kterým osobnost člověka může kultivovat svoji mysl, bez ohledu na

1 Článek vznikl za podpory grantového projektu SPEV „Př́nosy tréninku všímavé pozornosti“ řešeného na Ústavu sociální práce FF UHK (2016/2017).

2 Srov. Malcolm PAYNE, Modern Social Work Theory, Basingstoke: Palgrave Macmillan, 2014, s. 167-168.

3 Srov. Jon KABAT-ZINN, Život samá pohroma: Jak čelit stresu, nemoci a bolesti pomocí moudrosti těla a mysli, Brno: Jan Melvil Publishing, 2016; Daniel GOLEMAN, Základy meditace: meditující mysl, Praha: Triton, 2001; Mirko FRÝBA, Umění žít štastně: Buddhova Abhidhamma v praxi meditace a zvládání života, Praha: Argo, 2003; Mirko FRÝBA, Psychologie zvládání života: Aplikace metody Abhidhamma, Brno: Albert, 2008.

4 Srov. Daniel GOLEMAN, Destruktivní emoce, Praha: Ikar, 2004; Daniel GOLEMAN, Pozornost, Brno: Jan Melvil Publishing, 2014; Daniel SIEGEL, Vnitřní nazírání, Praha: Triton, 2014.

5 Srov. Mircea ELIADE, Jóga. Nesmrtelnost a svoboda, Praha: Argo, 1999, s. 240-264. 
základní hodnotové orientace, skrze které se vztahuje ke světu. Meditace byla v rámci neurověd interpretována jako trénink mindfulness (vědomé pozornosti, všímavosti), který lze doporučit v každé situaci, kdy je určitá osoba vedena k nácviku žádoucích jednání nutných pro dosažení jejího cíle, avšak postrádá ve významné míře kompetenci regulace svého chování. ${ }^{6}$ Je zřejmé, že takové situace velmi často nastávají i v každodenní praxi sociální práce s jednotlivci, a je zcela pochopitelné, že někteří autoři již navrhují integrovat trénink mindfulness do profesní výbavy sociálních pracovnic a pracovníků.?

Dříve než se trénink mindfulness stane standardní součástí zásobárny metod a technik, které v praxi sociální pracovníci každodenně užívají, je ovšem nutno do jisté míry porozumět základním principům této metody, a postavit tak její užívání v praxi na dostatečném teoretickém základě, bez kterého se nereflektované užívání tréninku mindfulness bude míjet požadovaným účinkem. V zahraničí tyto reflexe už probíhají, v českém prostředí je toto téma zatím spíše mimo zájem odborné veřejnosti.

Cílem tohoto př́ispěvku je přiblížit čtenáři konceptuální základnu tréninku mindfulness a popsat nejdůležitější dosavadní návrhy využití tréninku mindfulness v sociální práci, jakož i př́ípadná rizika, která při uplatňování této praxe hrozí. Věřím, že tento text dodá sebevědomí těm, kteří možná o užívání této metody uvažují a tuší v ní určitý potenciál, a pomůže nasměrovat jejich první kroky v praxi.

\section{Trénink mindfullness - konceptuální východiska}

Trénink mindfulness je $\mathrm{v}$ nejobecnější rovině cvičením vědomé pozornosti. ${ }^{8}$ Cílem je posílit schopnost jedince věnovat pozornost přítomné situaci specifickým způsobem: soustředěně a bez jakéhokoliv posuzování. ${ }^{9}$ Jedná se o sekulární podobu meditace, kdy cvičící osoby nesledují žádné zvolené spirituální cíle, ale usilují o posílení některých osobních kompetencí, jejichž užívání jim pomáhá zvládat a dále zkvalitňovat jejich životy. Tyto nespirituální cíle byly přítomny již $\mathrm{v}$ rámci některých meditačních systémů (zejména $\mathrm{v}$ buddhismu) a inspirovaly první modely užívání meditace v praxi pomáhajících profesí na Západě. ${ }^{10}$ Tyto zpơsoby práce s klientem mưžeme považovat za první příklady využívání tréninku mindfulness v našem kulturním okruhu a některé jejich postupy lze využívat i v rámci všeobecně známých metod sociální práce. V současné době ovšem trénink mindfulness zahrnuje daleko více různých technik a postupů, v jejichž jádru je cílené rozvíjení bdělé pozornosti cvičících. Některé z těchto technik vychází z tradičních meditačních metod buddhismu či jógy, mnoho dalších bylo vytvořeno v posledních desetiletích v praxi pomáhajících oborů, obvykle jako výsledek kombinací některých forem cvičení bdělé pozornosti a nejrůznějších technik $\mathrm{z}$ okruhu kognitivně-behaviorálních přístupů. Některé z těchto postupů jsou úzce zaměřeny na specifické skupiny klientů, některé jsou univerzálnějšího charakteru. Osvojit si tyto techniky je zpravidla možné prostřednictvím nejrůznějších kursů a workshopů, ale i samostudiem s využitím didakticky pojatých monografií, CD či DVD nosičů.

Cílem následujících podkapitol je popsat postupný vývoj teoretických východisek této metody, zahrnující dvě období: zmíněnou počáteční etapu přebírání některých prvků buddhistické psy-

6 Srov. PAYNE, Modern..., s. 167.

7 Srov. Steven F. HICK, Mindfulness and social work, Chicago: Lyceum Books, 2009; (c) Yuk-Lin Renita WONG, Knowing Through Discomfort: A Mindfulness-based Critical Social Work Pedagogy (on-line), dostupné na: http://www1.uwindsor.ca/criticalsocialwork/ knowing-through-discomfort-a-mindfulness-based-critical-social-work-pedagogy, citováno dne 29. 9. 2018.

9 Srov. KABAT-ZINN, Život samá pohroma..., s. 24.

10 Srov. KABAT-ZINN, Život samá pohroma...; Mirko FRÝBA, Psychologie zvládání života... 
chologie a následující etapu reflexe výsledků neurovědních výzkumů mozku, které otevřely využívání tréninku mindfulness v rámci pomáhajících profesí další možnosti.

\subsection{Východní kořeny tréninku mindfulnes}

Trénink mindfulness původně vychází z východní metody osobního „osvobození, která je v západním civilizačním okruhu po několik desetiletí označována jako meditace. Existuje mnoho typů meditace (např̀ v rámci hinduistické jógy, čínského taoismu či hinajánového a mahajánového buddhismu), nicméně pro tvưrce sekulárních podob tréninku mindfulness byly inspirující především ty techniky, které jsou ve svém jádru zaměřeny na trénink bdělé pozornosti. Při jejich cvičení je úkolem meditujících soustředit se na jediný objekt (např. na mantru, modlitbu, symbol, tělesný pocit, vlastní dech či v pokročilejších formách meditace na př́itomný okamžik), u kterého se snaží svojí pozorností po určitou dobu setrvat. Motivace $\mathrm{k}$ tomuto tréninku jsou podmíněny tradicí, ke které se cvičící hlásí, nicméně moment koncentrace pozornosti na jediný bod je v jejich cvičeních vždy prítomný. ${ }^{11}$

V posledních dekádách 20 . století zaznamenaly společenské vědy první pokusy o reflexi východních psychologických metod, které ovšem nedošly výraznějšího ocenění v praxi, pravděpodobně pro jejich nezápadní epistemologické založení. Přesto si v tomto kontextu určitě zaslouží zmínku spolupráce kognitivně-behaviorálně orientovaného autora Daniela Golemana s Tändzinem Gjamccho (současným dalajlámou) či ucelený psychoterapeutický směr satiterapie českého autora Mirko Frýby, který se při své konceptuální tvorbě přímo inspiroval metodami hinajánového buddhismu. ${ }^{12}$ Jejich poznatky o psychologii lidské osobnosti mají stále platnost. Na podkladě čistě empiricky založené buddhistické psychologie předpokládali určité hypotézy o lidské mysli, které neurovědní výzkumy přednedávnem potvrdily.

$\mathrm{K}$ těm nejdůležitějším názorům buddhistické psychologie o lidské mysli patří domněnka o principiální důležitosti všímavé pozornosti při dosahování našich každodenních i dlouhodobých cílů (a s tím prŕmo spojených pocitů spokojenosti v životě). V buddhismu je tato psychologie spojena s fundamentálními cíli lidského života, jak je definoval Gautama Buddha (vlastním jménem Siddhárta Gautama z rodu Šákjů), což je osvobození se z koloběhu zrození, jehož dosažení za obvyklých okolností brání neprospěšná chování pod vlivem vášní, které nás připoutávají a uvrhávají do dalších „vtělení. Jedním ze způsobů, jak tomu zabránit, je každou situaci pozorně reflektovat a vyhnout se neprospěšným chováním pod vlivem negativních emocí, kdy meditační cvičení jsou důležitým nástrojem pro posílení této kompetence.

Odhlédneme-li od těchto pro nás spiše exotických světonázorů, můžeme zjistit a uznat, že způsob zvládání nejrůznějších situací, kdy se bez podléhání vzrušenějším emocím orientujeme na společná a eticky obhajitelná řešení, je univerzálně platný. Podíváme-li se na modely aplikace této myšlenky v praxi, dostaneme obraz psychologie úspěšného zvládání nejrůznějších situací spojených s rizikem podlehnutí vášním a z toho plynoucím následkem zvolení destruktivního chování. ${ }^{13}$ Díky neurovědním výzkumům mozku ovšem nyní i víme, že trénink jednobodové meditace může skutečně ovlivnit naši schopnost podle této představy jednat.

11 Srov. Daniel GOLEMAN, Základy meditace....

12 Srov. Mirko FRÝBA, Umění žit štastně...; Mirko FRÝBA, Psychologie zvládání života....

13 Srov. Daniel GOLEMAN, Destruktivní emoce...; Tändzin GJAMCCHO - Howard C. CUTLER, Cesta ke štěstí: Průvodce dobrým životem, Praha: Pragma, 1999. 


\subsection{Trénink mindfullness jako téma neurovědných výzkumů}

Jak již bylo uvedeno, trénink mindfulness není podmíněn vírou v buddhistické či jiné náboženství. ${ }^{14}$ Odhlédneme-li od kulturního kontextu vzniku této metody a vnímáme její cvičení pouze jako behaviorální trénink vědomé pozornosti, jsme schopni vysvětlit a obhájit její užívání v praxi $\mathrm{v}$ př́mé práci s klienty z pohledu moderních neurověd, epistemologicky ukotvených $\mathrm{v}$ tradici západní vědy.

Podle dosavadních výzkumů pozornosti, které byly realizovány za pomoci nových zobrazovacích metod, byly zjištěny některé účinky tréninku pozornosti na úrovni neuronální architektury mozku, projevující se vznikem nových neuronových spojení mezi jeho jednotlivými částmi.

Goleman a Siegel uvádí závěry několika provedených studií, které mluví zejména o dopadech cvičení mindfulness na následující oblasti mozku.

1. Posílení neuronálních systémů ve fronto-parietální kůře, odpovědných za soustředění. Jedná se o systémy, které umožňují přenášení a udržování pozornosti na zvolené předměty mysli. ${ }^{15}$ Tyto neuronální systémy mimo jiné hrají zásadní úlohu v procesech učení, kdy užívání soustředěné pozornosti aktivuje nervové vzruchy $\mathrm{v}$ př́slušných částech mozku a stimuluje růst nových spojů mezi neurony. ${ }^{16}$

2. Snížení dráždivosti systému bloudivého nervu. Bloudivý nerv ovládá některé fyziologické funkce, které ve stresové situaci reagují zvýšenou aktivitou. Snížená úroveň dráždivosti tohoto nervu pomáhá zachovat v emočně náročné situaci vy̌̌ší míru rozvahy. ${ }^{17}$

3. Posílení funkce zrcadlových neuronů. $S$ ohledem na to, že neuronální okruhy zodpovědné za pozornost jsou těsně propojeny s okruhy zrcadlových neuronů, posilují se tak i schopnosti empatie, která je důležitou komponentou úspěchu v sociálních vztazích. ${ }^{18}$

Strukturální změny v architektuře mozku mají vliv i na jeho funkce. Posílení výše uvedených oblastí mozku se dle meditujících osob projevuje v odlišné intenzitě prožívání mnoha duševních stavů a v rozvoji některých duševních schopností. V současné literatuře již nalezneme závěry mnoha studií, které popisují různé přínosy pravidelného tréninku mindfulness. Např. Hick uvádí následující benefity tohoto cvičení: jasné vědomí myšlenek a emocí; získání schopnosti přistupovat k bolesti a obtížím novými způsoby; posílení schopnosti vyrovnat se s emocionálním rozrušením; rozvoj kreativního myšlení; rozvoj sebeuvědomění a následné pozitivní vnímání sebe sama; větší pocit pohody; schopnost reagovat efektivněji na stres či schopnost rozhodovat $s$ větší jasností a uvědoměním. ${ }^{19}$ Jiní autoři, jako např. Ellen Langer a Mihnea Moldoveanu, zdůrazňují účinky tréninku mindfulness na proces učení, kdy cvičení mindfulness zřejmě posiluje naši schopnost koncentrace a podporuje pamět. ${ }^{20} \mathrm{Za}$ zmínku určitě stojí i posílení imunitního systému či snížení fyzických dopadů stresu na tělo. ${ }^{21}$

Díky těmto pozitivním účinkům praktikování tréninku mindfulness na duševní zdatnost cvičících osob je $\mathrm{v}$ poslední době této metodě věnována pozornost i mnoha profesionálů $\mathrm{z}$ oboru sociální práce, kteři si uvědomují její pozitivní př́nosy při práci s různými skupinami klientů.

14 Srov. Steven F. HICK, Mindfulness and Social Work..., s. 3.

15 Srov. GOLEMAN, Pozornost..., s. 202.

16 Srov. Daniel SIEGEL, Vnitřní nazírání, Praha: Triton, 2014, s. 108-109.

17 Srov. GOLEMAN, Pozornost..., s. 202.

18 Srov. SIEGEL, Vnitřní..., s. 83, 110.

19 Srov. HICK, Mindfulness and Social Work..., s. 9-10.

20 Srov. Ellen J. LANGER - Mihnea MOLDOVEANU, The Construct of Mindfulness, Journal of Social Issues 2000/1, s. 3-4.

21 Srov. Dharma Singh KHALSA, Stress, Meditation, and Alzheimer's Disease Prevention: Where The Evidence Stands, Journal of Alzheimer's Disease 1/2015, s. 1-12. 
Některé z těchto oblastí přiblíží následující kapitola, shrnující výzkumy, které byly na půdě sociální práce realizovány.

\section{Trénink mindfullness v sociální práci}

Obecně lze říci, že v sociální práci je trénink mindfulness využíván obvykle v situacích, kdy osoba klienta ve významné míře postrádá kompetenci regulace některých aspektů svého chování. ${ }^{22}$ V těchto momentech se cvičení mindfulness může stát dílčí součástí strategie celé intervence ve prospěch klienta. Cílem této kapitoly je představit některé příklady využívání tréninku mindfulness ve vybraných oblastech sociální práce, kde již bylo cvičení vědomé pozornosti experimentálně ověřeno a přineslo kladné výsledky.

\section{Sociální práce s lidmi s depresí}

V sociální práci bylo možné poprvé zaznamenat úspěšné využívání tréninku mindfulness v oblasti spolupráce s klienty trpícími depresí, se kterými se sociální pracovnice a pracovníci ve své praxi setkávají poměrně často. Obvykle to je v rámci různých multidisciplinárních týmů, zaměřených na komplexní rehabilitaci lidí, kteří jsou následkem své nemoci nějakým způsobem sociálně hendikepováni. Sociální pracovníci mohou těmto osobám poskytovat různé typy poradenství (individuální, rodinné, krizové) a často také mohou prostřednictvím case managementu mobilizovat $\mathrm{v}$ jejich prospěch různé podpůrné sítě. $\mathrm{V}$ rámci týmové spolupráce koordinují své aktivity s psychiatry a psychology, kteř́ jsou odpovědní za farmakologickou léčbu a psychoterapeutickou péči. Vedle toho taktéž komunikují s rodinou klienta a dle potřeby s jeho nebližším sociálním okolím. Dosavadní realizované výzkumné studie vedou k závěru, že aplikace tréninku mindfulness v oblasti sociální práce s osobami s depresí je možná a v určitých směrech přínosná. Vyškolení sociální pracovníci a pracovnice mohou ve spolupráci s lékaři nabízet klientům podpůrnou terapii založenou na specifickém typu tréninku mindfulness, který může dobře posilovat účinky léčby antidepresivy a odborné psychoterapie. ${ }^{23}$ Jedná se konkrétně o prŕístup vyvinutý Jonem Kabat-Zinnem, zaměřený na redukci stresu a úzkosti („mindfulness-based stress reduction“), jehož užití má i některé prokazatelné výsledky při léčbě depresí. Cvičení tréninku mindfulness má především pozitivní vliv na zvládání relapsů deprese (srovnatelný s účinky antidepresiv v udržovací fázi léčby), nebot posiluje schopnosti klientů zvládat kognitivní př́iznaky deprese, jako je např̀. zkreslené myšlení, potíže s koncentrací a poruchy paměti. S ohledem na to, že tyto symptomy mohou narušit všechny oblasti života klientů, včetně jejich uspokojivého fungování ve společnosti (a dále tak zhoršovat jejich stav), je z pohledu sociální práce určitě vhodné zaměřovat se v rámci péče o klienty i na posilování kompetencí spojených se soustředěnou pozorností. Metody založené na mindfulness jsou v tomto př́padě osvědčenou pomocí. ${ }^{24}$

22 Srov. PAYNE, Modern..., s. 167

23 Srov. Steven F. HICK - Levia CHAN, Mindfulness-Based Cognitive Therapy for Depression: Effectiveness and Limitations, Social Work in Mental Health 3/2010, s. 225-237.

24 Srov. Tomoko SUGIURA - Yoshinori SUGIURA, Common Factors of Meditation, Focusing, and Cognitive Behavioral Therapy: Longitudinal Relation of Self-Report Measures to Worry, Depressive, and Obsessive-Compulsive Symptoms Among Nonclinical Students, Mindfulness 6/2015, s. 619; Tomoko SUGIURA - Yoshinori SUGIURA, Cognitive decentering: Relation to constructs from cognitive behavioral therapy and positive psychology, in: Psychology of Mindfulness, ed. Kimiyo MURATA-SORACI, New York: Nova Science Publishers, 2014, s. 58-61. 


\section{Péče o osoby s demencí}

Trénink mindfulness může být vítaným pomocníkem i v péči o osoby s demencí. I když je demence ze své podstaty nevyléčitelná, lze některé její příznaky mírnit či zpomalovat jejich nástup a vedle toho i přemýšlet o zachování prìijatelné úrovně kvality života osob s tímto onemocněním. $S$ ohledem na to, že demence zapříčiňuje především úpadek kognitivních schopností i zvýšení výskytu negativních emocí u takto nemocných jedinců, je to právě trénink mindfulness, o kterém lze uvažovat o jako nanejvýš vhodném podpůrném prostředku, kterým lze projevy některých z těchto symptomů tlumit. Dosavadní realizované výzkumné studie zatím potvrdily pozitivní efekt cvičení tréninku mindfulness v prevenci výskytu stresových stavů u nemocných osob, kdy cvičící osoby uváděly snižení výskytu průvodních příznaků stresu, jako jsou stavy úzkosti a nespavost, prokázán byl také snížený výskyt různých zánětů, poruch regulace vápníku, kardiovaskulárních onemocnění včetně hypertenze či cukrovky. ${ }^{25}$ Neméně důležitým prokázaným př́nosem tréninku mindfulness je také zmírnění stavů deprese, kdy se ukazuje, že i osoby stižené progresivním úbytkem kognitivních funkcí stále dokážou za pomoci bdělé pozornosti zacházet se svými negativními emocemi, tedy udržovat si vůči objevujícím se negativním emocím odstup a přeorientovávat svoji pozornost na pozitivnější duševní obsahy.

Mezi nepotvrzené př̀edpoklady patří hypotéza, že trénink mindfulness má u osob s demencí pozitivní vliv na pamět a kognitivní funkce, stejně jak tomu je u zdravých osob. Odmyslíme-li relativní zlepšení těchto funkcí v př́ípadě odstranění pocitů stresu a deprese díky cvičení tréninku mindfulness, nepřinesla žádná studie jednoznačné potvrzení jakéhokoliv vlivu na zvrácení či zbrzdění průběhu nemoci jako takové, i když výzkum této problematiky nadále pokračuje. ${ }^{26}$ Jak naznačují výzkumy vlivu tréninku mindfulness na pamèt osob s mírnou kognitivní poruchou, mohla by tato metoda být smysluplně využita alespoň v raných stádiích výskytu demence. ${ }^{27}$

\section{Práce se studenty a žáky s poruchami učení}

V sociální práci s dětmi a mladými lidmi se pracovníci často potkávají se studenty a žáky se specifickými poruchami učení. Ve vyšší míre než jejich vrstevníci zažívají tito jedinci ve spojitosti se školou více pocitů úzkosti a stresových stavů, což nezř́́dka negativně ovlivňuje jejich školní chování a často taktéž i jejich plnění povinné školní docházky. To dále může negativně ovlivňovat i jejich úspěšnost v osvojování si učiva a sociálních dovedností. Všechny zmíněné faktory se mohou navzájem posilovat a jen obtížně se nachází cesta ven z těchto bludných kruhů.

Pozitivní úlohu při řešení těchto obtíží může vedle standardních postupů sociální práce sehrát trénink mindfulness. To alespoň naznačuje pilotní studie Beauchemina, Hutchinsové a Pattersonové $^{28}$, která byla zaměřena právě na snižování úzkostí a posilování sociálních dovedností žáků se specifickými poruchami učení prostřednictvím tréninku mindfulness. V souladu s teoretickými očekáváními studie skutečně potvrdila výrazný pokles míry stresu po pěti týdnech pravidelného

25 Srov. KHALSA, Stress..., s. 1-12.

26 Srov. (c) Gina L. HEMMESCH, Exploring the Use of Mindfulness with Individuals Diagnosed with Alzheimer's Disease (on-line), dostupné na: http://sophia.stkate.edu/msw_papers/462, citováno dne 13. 10. 2018.

27 Srov. (C) Rebecca Erwin WELLS - Gloria Y. YEH - Catherine E. KERR - Jennifer WOLKIN - Roger B. DAVIS - Ying TAN - Rosa SPAETH - Robert WALL - Jacquelyn WALSH - Ted KAPTCHUK - Daniel PRESS - Russell S. PHILLIPS - Jian KONG, Meditation's impact on default mode network and hippocampus in mild cognitive impairment: a pilot study (on-line), dostupné na: https://www.ncbi.nlm.nih. gov/pmc/articles/PMC4022038/, citováno dne 13. 10. 2018.

28 Srov. James BEAUCHEMIN - Tiffany L. HUTCHINS - Fiona PATTERSON, Mindfulness Meditation May Lessen Anxiety, Promote Social Skills, and Improve Academic Performance Among Adolescents With Learning Disabilities, Complementary Health Practice Review $1 / 2008$, s. 34-45. 
tréninku mindfulness u 34 sledovaných studentů středních škol, kteří měli diagnostikovánu poruchu učení. Výrazné zlepšení bylo ovšem zaznamenáno i při hodnocení jejich sociálních kompetencí a stejně tak $\mathrm{v}$ případě jejich školních výkonů. Tyto výsledky je nutno brát jako předběžné, ale i když se jedná o specifickou skupinu, není zde podstatný důvod se domnívat, že by její příslušníci měli na trénink mindfulness reagovat jinak než standardní vzorek populace, kde několik studií prokázalo obdobné účinky. ${ }^{29}$ Závěry Beauchemina, Hutchinsové a Pattersonové taktéž podporují výzkumy zaměřené na redukci projevů ADHD prostřednictvím tréninku mindfulness, které realizovali Van der Oord a kol. (2012), Weijer-Bergsma a kol. (2012) a Herman H. M. Lo a kol. (2016). ${ }^{30} \mathrm{~S}$ ohledem na to, že ADHD a specifické poruchy učení se často vyskytují pospolu, lze předpokládat, že nejrůznější odlišnosti ve fungování centrální nervové soustavy těchto žáků nejsou zásadní překážkou pro využití tréninku mindfulness v jejich prospěch.

\section{Sociální práce s uživateli drog}

Odolnost vůči touze po uspokojení potřeb v krátkodobém časovém horizontu ve prospěch větších zisků v dlouhodobé perspektivě je schopnost, kterou uživatelé návykových látek zpravidla nedisponují v potřebné míře. I když jsou si vědomi škodlivých budoucích následků užívání těchto substancí, nedokáží odolat pocitům bažení, které je k nim přitahují. Užitečnou kompetencí př̀i odolávání těmto pokušením (i dalším jiným) je dovednost přerušit proces bažení odvedením vnitřní pozornosti od předmětu touhy jiným směrem. ${ }^{31}$ Jak vyplývá $\mathrm{z}$ mnoha realizovaných studií, osvědčeným prostředkem pro posílení této kompetence je trénink mindfulness. Ten můžeme vnímat jako užitečný nástroj především při odvykání i dále v kontextu strategií prevence relapsu. ${ }^{32}$ Trénink mindfulness má výrazné výsledky především u klientů s těmito charakteristikami: 1) uživatelé s hlubším stupněm závislosti, kteří mají dobré důvody obávat se příchodu negativních zdravotních a dalších dopadů užívání a jsou tím motivováni ke změně; 2) zároveň se často jedná o lidi, kteří užívají drogy kvůli zvládání určitého stresu, úzkostí či jiného nepohodlí v jejich životech. ${ }^{33}$

Při odvykací léčbě a v prevenci relapsu trénink mindfulness zpravidla pomáhá klientům odolávat nutkavým myšlenkám na užití drogy. Obvyklou strategií zvládání těchto nutkání je posílení schopnosti klienta včas rozpoznat známky bažení po droze, což zahrnuje zvýšenou pozornost vůči vnitřním (emocionálním a kognitivním) a vnějším (situačním) stimulům, spojeným s užíváním

29 Srov. Kimberly A. SCHONERT-REICHL - Eva OBERLE - Molly Stewart LAWLOR - David ABBOTT - Kimberly THOMSON - Tim F. OBERLANDER - Adele DIAMOND, Enhancing Cognitive and Social-Emotional Development Through a Simple-to-Administer Mindfulness-Based School Program for Elementary School Children: A Randomized Controlled Trial, Developmental Psychology 1/2015, s. 52-66; (c) Charlotte ZENNER - Solveig HERRNLEBEN-KURZ - Harald WALACH, Mindfulness-based interventions in schools - a systematic review and meta-analysis (on-line), dostupné na: https://www.frontiersin.org/articles/10.3389/fpsyg.2014.00603/ full, citováno dne 14. 10. 2018.

30 Srov. ( ) Saskia VAN DER OORD - Susan M. BÖGELS - Dorreke PEIJNENBURG, The Effectiveness of Mindfulness Training for Children with ADHD and Mindful Parenting for their Parents (on-line), dostupné na: https://www.ncbi.nlm.nih.gov/pmc/articles/ PMC3267931/, citováno dne 14. 10. 2018; @ Eva van de Weijer-Bergsma - Anne R. Formsma - Esther I. de Bruin - Susan M. Bögels, The Effectiveness of Mindfulness Training on Behavioral Problems and Attentional Functioning in Adolescents with ADHD (on-line), dostupné na: https://www.ncbi.nlm.nih.gov/pmc/articles/PMC3438398/, citováno dne 14. 10. 2018; @ Herman H. M. LO - Samuel Y. S. WONG - Janet Y. H. WONG - Simpson W. L. WONG - Jerf W. K. YEUNG, The effect of a family-based mindfulness intervention on children with attention deficit and hyperactivity symptoms and their parents: design and rationale for a randomized, controlled clinical trial (Study protocol) (on-line), dostupné na: https://www.ncbi.nlm.nih.gov/pmc/articles/PMC4791862/, citováno dne 14. 10. 2018. Srov. Walter MISCHEL, Marshmallow test - Jak se naučit sebekontrole, Praha: Ikar, 2015.

32 Přehled nejdůležitějších studií na toto téma viz (c) Sarah BOWEN - Matthew C. ENKEMA, Relationship between Dispositional Mindfulness and Substance Use: Findings from a Clinical Sample (on-line), dostupné na: https://www.ncbi.nlm.nih.gov/pmc/articles/ PMC3909670/, citováno dne 3. 11. 2018.

33 Srov. tamtéž. 
této látky, a vytváření určitých dovedností (či technik) pro zvládání těchto situací. ${ }^{34}$ Je zřejmé, že trénink bdělé pozornosti může být silným podpůrným prostředkem ve všech těchto procesech. Realizované výzkumné studie potvrzují několik pozitivních dopadů cvičení na schopnosti klienta. Ukázalo se, že klienti, kteří se díky cvičení mindfulness naučili lépe manipulovat svojí pozorností, si dokážou častěji udržet indiferentní vztah $\mathrm{k}$ myšlenkám a pocitům spojeným s návykovou látkou, čímž tlumí eskalaci vzorců, které mohou vést $\mathrm{k}$ jejímu opětovnému užití. Tyto úspěchy mají tendenci se opakovat a vytváří se určitý vzorec chování, díky kterému klienti nakonec dokáží přerušit „návykovou smyčku“ ${ }^{35}$ Dalším pozitivním efektem tréninku mindfulness je pokles výskytu faktorů často souvisejících s relapsem, jako jsou např. pocity úzkosti, deprese či stresu, které bývají obvyklou součástí našich životů při zvládání nejrůznějších každodenních záležitostí. Díky trvalému ovlivnění schopnosti seberegulace emocí se redukuje frekvence výskytu negativních pocitů, které dříve byly často aktivním spouštěčem bažení po droze. ${ }^{36}$ Nové studie ukázaly, že potenciál dosáhnout výše uvedených výsledků tréninku mindfulness má každý cvičící klient, bez ohledu na jeho třídní či etnický původ, dosažené vzdělání, příjem, nebo dokonce zkušenosti s chudobou, bezdomovectvím či násilím. ${ }^{37}$

\section{Spirituálně senzitivní sociální práce}

Jistě není žádným překvapením, že trénink mindfulness má své místo i v praxi spirituálně senzitivní sociální práce. Je zřejmé, že svým původem v náboženských systémech Východu a díky své podobě a mnoha společnými znaky s některými kontemplačními metodami Západu je předurčen k širokému užití v rámci spolupráce sociálních pracovníků a klientů z různých kulturních prostředí. ${ }^{38}$ Cvičení bdělé pozornosti stojí v jádru významně velkého počtu meditačních a kontemplačních metod všech světových náboženství, kde jsou tyto metody všeobecně oceňovány jako základní pilíře spirituálního života jejich členů. ${ }^{39} \mathrm{~V}$ kontextu spirituálně senzitivní sociální práce lze tyto tradiční metody považovat za způsob posílení klientovy kompetence rozvíjet svůj spirituální život, což je v tomto přístupu legitimní cíl spolupráce.$^{40}$ Cvičení bdělé pozornosti zde tedy není primárně zaměřeno na posílení dílčích osobních kompetencí klienta, s jejichž pomocí by měl řešit své osobní a interpersonální problémy, jak tomu bývá při standardním využívání „sekulárních“ technik tréninku mindfulness, na druhou stranu se i tyto fenomény často objevují jako vedlejší benefity praxe. ${ }^{41}$

Ne všichni následovníci zmíněných náboženství se cvičení těchto metod věnují, na druhou stranu je ovšem možné říci, že oproti minulosti je aktivní duchovní praxe součástí života nejen mnišských komunit, ale i mnohých laiků. Praktikování nejrůznějších meditačních a kontemplačních

34 Srov. ( ) Sarah BOWEN - Neharika CHAWLA - Susan E. COLLINS - Katie WITKIEWITZ - Sharon HSU - Joel GROW - Seema CLIFASEFI - Michelle GARNER - Anne DOUGLASS - Mary E. LARIMER - Alan MARLATT, Mindfulness-Based Relapse Prevention for Substance Use Disorders: A Pilot Efficacy Trial (on-line), dostupné na: https://www.ncbi.nlm.nih.gov/pmc/articles/PMC3280682/, citováno dne 3.11.2018.

35 Srov. ( ) Katie WITKIEWITZ - Sarah BOWEN - Erin N. HARROP - Haley DOUGLAS - Matthew ENKEMA - Carly SEDGWICK, Mindfulness-Based Treatment to Prevent Addictive Behavior Relapse: Theoretical Models and Hypothesized Mechanisms of Change (on-line), dostupné na: https://www.ncbi.nlm.nih.gov/pmc/articles/PMC5441879/, citováno dne 3. 11. 2018.

36 Srov. @ BOWEN - ENKEMA, Relationship...

37 Srov. () Eric L. GARLAND - Charlotte A. BOETTIGER - Susan GAYLORD - Vicki WEST CHANON - Matthew O. HOWARD, Mindfulness is Inversely Associated with Alcohol Attentional Bias Among Recovering Alcohol-Dependent Adults (on-line), dostupné na: https://www.ncbi.nlm.nih.gov/pmc/articles/PMC3532517/, citováno dne 3. 11. 2018.

38 Srov. Edmund SHERMAN - Max SIPORIN, Contemplative Theory and Practice for Social Work, Journal of Religion \& Spirituality in Social Work: Social Thought 3/2008, s. 260-261.

39 Srov. tamtéž, s. 260-261.

40 Srov. tamtéž, s. 269.

41 Srov. Wilfrid STINISSEN, Křestanská hlubinná meditace, Kostelní Vydří: Karmelitánské nakladatelství, 2007, s. 14. 
metod je věcí individuální volby věřících, přičemž většina církví nejenže tuto skutečnost toleruje, ale i aktivně podporuje pořádáním různých seminářo̊, workshopů a duchovních setkání pro laiky z prostředí církve i mimo ni či publikováním nejrůznějších knih a článků na toto téma. Je to přirozená reakce na poznatky psychologů jako je např. John Dewey či Abraham Maslow, kteří tvrdí, že spiritualita je „lidský fenomén a že je základnější a původnější než tradiční, institucionální vyjádření religiozity “ ${ }^{42}$

Sociální pracovníci mohou při hledání klientových zdrojů oceňovat a posilovat spirituální stránku jeho osobnosti, ve které mohou oprávněně vidět faktor pozitivně ovlivňující klientovu motivaci ke změně jeho situace, vnímané v širším kontextu jeho života. ${ }^{43}$ Podporují klientovy aktivity rozvíjející jeho spirituální život, včetně různých meditativních cvičení, která lze nalézt v rámci každé náboženské tradice. ${ }^{44}$ Praktikování tréninku mindfulness ve formě určité tradiční meditační či kontemplační praxe (vedle dalších spirituálních metod a technik) může u cvičících osob rozvíjet a prohlubovat vědomí jisté „Zakořeněnosti“ jejich života v Bohu či v obecnější rovině (v případě nereligiózní formy spirituality) v Bytí. ${ }^{45} \mathrm{~V}$ souvislosti s tímto procesem se postupně mění perspektiva nahlížení života a objevují se nové postoje k životním obtížím, se kterými se tyto osoby každodenně setkávají. Objevuje se pocit pozitivní sebedůvěry, ale i důvěra v eticky přijatelná řešení těchto situací. Mění se vztahy k druhým lidem, ke společnosti či životnímu prostředí, kdy v pozadí je stále více př́tomná motivace pracovat pro jejich dobro. Meditace je tak „zdrojem“ nejen individuálně pojaté práce, ale případně i komunitní práce, zaměřené na nastolení či posílení sociální spravedlnosti pro celé skupiny ve společnosti. ${ }^{46}$

Výše uvedené pochopitelně platí i pro spirituálně senzitivní sociální práci v křestanském prostředí. Křestanská tradice zná mnoho různých kontemplativních a meditačních technik, o kterých můžeme jako sociální pracovníci podávat klientům potřebné informace a zhodnocení jejich zaměření. Více $\mathrm{z}$ nich sice propojuje kontemplační praxi s využitím diskursivního rozumu, vůle, afektivity a obrazotvornosti ${ }^{47}$, ale nalezneme i techniky, které jsou svým charakterem praxe postaveny více na užívání a posilování vědomé pozornosti. Ty mohou být s ohledem na soudobé kulturní trendy vhodné pro velký počet věřících klientů. Příkladem za všechny můžou být křest̉anská meditace Johna Maina či křestanská hlubinná meditace Wilfrida Stinissena, ale i mnoho dalších postupů, inspirovaných populárními autory jako Anthony de Mello, Hugo M. Enomiya-Lassalle či Franz Jalics. Tyto techniky se těší široké oblibě a dá se i předpokládat další růst zájmu o tyto v minulosti pozapomenuté typy kontemplativních modliteb.

Mluvíme-li v kontextu křestanské spirituálně senzitivní sociální práce o podpoře technik využívajících a posilujících vědomou pozornost, je určitě vhodné zdůraznit, že v tomto kontextu není na místě snažit se jakkoliv hodnotit výsledky cvičení. Cílem křestanské spirituální praxe nejsou nějaké konkrétně měřitelné benefity (at již mluvíme o posilování osobních kompetencí cvičících osob či dosahování určitých stupňů spirituálního růstu, jak to známe z východních spirituálních tradicí), ale další prohlubování vztahu s Bohem. I když lze nalézt několik studií týkajících se různých forem křestanské meditace, které hodnotí dopady pravidelné meditační praxe obdobnými slovy jako studie zaměřené na sekulárnější podoby tréninku mindfulness ${ }^{48}$, nikdo z jejich autorů

2 SHERMAN - SIPORIN, Contemplative..., s. 262.

43 Srov. Edward R. CANDA - Leola DYRUD FURMAN, Spiritual Diversity in Social Work Practice: The Heart of Helping, New York: OXFORD University Press, 2010, s. 244-247.

44 Srov. tamtéž, s. 199-200, 330-344.

45 Srov. SHERMAN - SIPORIN, Contemplative..., s. 268.

46 Srov. Dorothee SÖLLE, Mystika a vzdor, Praha: One Woman Press, 2015.

47 Srov. STINISSEN, Krestanská..., s. 13.

48 Srov. (C) Paul FALLER, Is Meditation a Thing for Children? (on-line), dostupné na: https://www.academia.edu/30973806/Is_ 
nezastává názor, že by křest’anská meditace měla být praktikována pouze a především pro tyto př́nosy. Křestanská meditace je druh modlitby a ne technika osobního seberozvoje. A jako křest’anská modlitba může mít i křest’anská meditace taktéž uzdravující charakter. ${ }^{49}$ Avšak jedná se o dary, které si nelze vynutit cvičením.

\section{Nežádoucí účinky a potenciální rizilka tréninku mindfullness}

Výrazný zájem pomáhajících profesí o fenomén tréninku mindfulness sebou přinesl také diskuse o účinnosti tohoto cvičení a jeho možných rizicích. Kritické připomínky směřovaly především ke koncepčním a metodologickým nedostatkům realizovaných studií a jisté schematičnosti učiněných závěrů, které opomíjely skutečnost, že každý cvičící jedinec reaguje na trénink mindfulness poměrně individuálně. Což může znamenat i situace, kdy praktikování tréninku mindfulness nemusí být vždy ku prospěchu klienta. Za prvé mu nemusí přinést prospěch žádný, anebo v horším případě můžou být efekty cvičení dokonce i negativní. ${ }^{50}$

Dosavadní reflexe tohoto tématu přinesla několik poznatků, které je zapotřebí brát v praxi v úvahu. Prvním důležitým námětem k reflexi je již např. otázka, proč by praxe tréninku mindfulness měla být účinná při rozvíjení nejrůznějších duševních kompetencí. Určitě lze akceptovat předpoklad, že vědomá pozornost (všímavost) je vrozená lidská kognitivní schopnost, jejíž pravidelné uplatňování může být často užitečné. Ale stále zde zůstává otázka, nakolik je trénink mindfulness při posilování této schopnosti účinný. ${ }^{51}$ Projeví se tyto efekty v každém našem jednání vyžadujícím soustředěnou pozornost? Lze s jistotou potvrdit, že se nejedná o samoúčelné cvičení, kdy člověk cvičí svoji pozornost jen pro zvládání specifických požadavků zvoleného typu praxe mindfulness bez jakýchkoliv přesahů do běžného života? Je reálné předpokládat, že silná schopnost uvědomovat si, co přináší přítomný okamžik, dokáže posilnit naše rozhodnutí nepodlehnout určité tendenci naší mysli (např. nutkání k určitým jednáním, prožívání určitých pocitů, sklonům k zacyklenému myšlení apod.)? Několik studií z poslední doby dosvědčuje, že na předchozí otázky nejde odpovědět vždy jednoznačně kladně. Např. Farias a Wikholmová uvádí výsledky několika randomizovaných studií zaměřených na užití tréninku mindfulness př̀i terapii depresí, stresu a úzkostných stavů, ze kterých vyplývá, že celkově není tato metoda účinnější než ostatní standardní př́stupy. Prokázána byla jen mírná zlepšení stavů deprese a úzkosti a velmi malá zlepšení při redukci stresu. Naopak nebylo nijak přesvědčivě prokázáno, že by cvičení mindfulness měla vliv na jiné proměnné, jako je pozitivní nálada, pozornost, spánek nebo užívání návykových látek. ${ }^{52}$ Ukazuje se tedy, že trénink mindfulness není žádný zázračný všelék, jeho výsledky jsou obdobné dalším uznávaným přístupům. Na druhou stranu se ovšem ukazuje i to, že realizované výzkumy často trpí různými možnými metodologickými nedostatky. Pokud uskutečněné studie vykazují různé závěry, je zapotřebí věnovat pečlivější pozornost různým proměnným. Jsou na místě otázky, jestli všichni respondenti praktikují stejný typ tréninku mindfulness (a jaký, příp. jaké?), filozofické či náboženské pozadí užívané techniky, doba trvání a frekvence cvičení, délka praxe a nakonec i vlastní formulace otázek, které se týkají tak něčeho subtilního, jako je

Meditation_a_Thing_for_Children, citováno dne 11.3.2019; ( Jinse Kim, The Efficacy Of Christian Devotional Meditation On Stress, Anxiety, Depression, And Spiritual Health With Korean Adults In The United States: A Randomized Comparative Study (on-line), dostupné na: https://digitalcommons.liberty.edu/cgi/viewcontent.cgi?article=1953\&context=doctoral, citováno dne 11. 3. 2019.

Srov. STINISSEN, Křestanská..., s. 14.

50 Srov. ( ) Miguel FARIAS - Catherine WIKHOLM, Has the science of mindfulness lost its mind? (on-line), dostupné na: https://www. ncbi.nlm.nih.gov/pmc/articles/PMC5353526/, citováno dne 4. 12. 2018.

51 Srov. tamtéž.

52 Srov. tamtéž 
naše duševní prožívání.

Další kritické ohlasy se týkaly negativních zkušeností, které sebou může trénink mindfulness přinášet. O těch první výzkumné studie zpravidla nemluvily. Ovšem v posledním období začíná být zřejmé, že s těmito efekty se už mohl setkat nejeden cvičící. Např. průřezová studie Deanea Shapira o účincích intenzivního a dlouhodobého cvičení mindfulness uvádí, že celých 62,9\% respondentů zaznamenalo alespoň jeden negativní účinek, jako jsou např. zvýšená úzkost, deprese, dočasná dezorientace po cvičení, jistá odtažitost od ostatních lidí či dokonce plně rozvinuté psychotické stavy. ${ }^{53}$ Mezi další zjištěné negativní účinky patří pocity depersonalizace ${ }^{54}$, tvorba falešných vzpomínek ${ }^{55}$, odstup od emocí (včetně těch pozitivních), vyhýbání se náročnějším myšlenkovým činnostem, ztráta chuti k jídlu, nespavost, poruchy výkonné paměti ${ }^{56}$ či nechtěné vynoření se traumatických vzpomínek z podvědomí. ${ }^{57}$ Jedná se sice spíše o zážitky epizodického charakteru, zpravidla vlastními silami zvládnutelné, kdy cvičící osoby obvykle dále pokračují ve své praxi, nebơ ta jim přináší více pozitivních než negativních výsledků, přesto se zdá, že určitá opatrnost při cvičení mindfulness je na místě. ${ }^{58}$ Osoby se sklony k výše uvedeným zkušenostem budou jistě i mezi klienty sociálních pracovníků a ti by měli s výskytem těchto jevů počítat. V případech, kdy klienti mají diagnostikované některé duševní onemocnění, by měli užívání tohoto cvičení konzultovat s jejich lékaři, u ostatních klientů by měli alespoň průběžně vyhodnocovat jejich zkušenosti s cvičením i s ohledem na možná zhoršení v některých oblastech jejich životů. Ideální by samozřejmě bylo, kdyby mohli sociální pracovníci absolvovat ucelený akreditovaný výcvik metody mindfulness pro pomáhající profese, $v$ rámci kterého by se naučili hrozící rizika včas rozpoznávat a př́p. terapeuticky zvládat, nicméně v současné době kromě krátkodobých kurzů nic takového nefunguje..$^{59}$

\section{Shrnutí}

Cílem tohoto příspěvku bylo přiblížit konceptuální základy tréninku mindfulness a popsat nejdůležitější dosavadní návrhy jeho využití v sociální práci. V návaznosti na tento cíl byly ve stručnosti uvedeny náboženské kořeny této metody a současná reflexe tréninku mindfulness z pohledu neurověd. Byla zdůrazněna orientace tréninku mindfulness na posílení schopnosti člověka zdržet se vědomě určitých typů chování, které nejsou přínosné. Tato orientace byla v popředí už v buddhistické tradici meditace a v zásadě se jí přidržují i dnešní směry tréninku mindfulness. Díky moderním zobrazovacím metodám mozku víme, na které oblasti neuronální architektury mozku má pravidelné cvičení mindfulness posilující vliv, a dokážeme identifikovat určitou souvislost mezi těmito účinky a subjektivně vnímanými posuny v rozvoji některých kompetencí, týkajících se seberegulace chování, které potvrdili cvičící informanti v rámci doposud realizovaných výzkumných studií.

O většině těchto kompetencí můžeme říci, že je lze v kontextu praxe sociální práce vnímat jako

53 Srov. Deane SHAPIRO, Adverse Effects of Meditation: A Preliminary Investigation of Long-Term Meditators, International Journal of Psychosomatics 39/1992, s. 64-65.

54 Srov. M. Kathleen B. LUSTYK - Neharika CHAWLA - Roger S. NOLAN - G. Alan MARLATT, Mindfulness Meditation Research: Issues of Participant Screening, Safety Procedures, and Researcher Training, Advances in Mind-Body Medicine 1/2009, s. 22, 24,

55 Srov. J. David CRESWELL, Mindfulness Interventions, Annual Review of Psychology 1/2017, s. 508.

56 Srov. () Utpal DHOLAKIA, The Little-Known Downsides of Mindfulness Practice (on-line), dostupné na: https://www.psychologytoday. com/us/blog/the-science-behind-behavior/201604/the-little-known-downsides-mindfulness-practice, citováno dne 4. 12. 2018.

57 Srov. () William VAN GORDON - Edo SHONIN - Javier GARCIA-CAMPAYO, Are there adverse effects associated with mindfulness? (on-line), dostupné na: http://journals.sagepub.com/doi/10.1177/0004867417716309, citováno dne 4. 12. 2018.

58 Srov. CRESWELL, Mindfulness..., s. 507-509.

59 Srov. () FARIAS -WIKHOLM, Has the science... 
klíčové pro realizaci žádoucích změn v životech našich klientů. Je proto pochopitelné, že v oboru sociální práce začaly být nejrůznější varianty tréninku mindfulness postupem času využívány. Tento text nabídl několik príkladů z praxe sociální práce, kde se využití tréninku mindfulness ukázalo být úspěšné. Jako př́ílady skupin klientů, které mohou mít $\mathrm{z}$ cvičení mindfulness prospěch, byly zmíněny osoby s depresí, osoby trpící demencí, studenti a žáci s poruchami učení či uživatelé návykových látek. $V$ literatuře lze ovšem nalézt další oblasti sociální práce, kde je trénink mindfulness experimentálně využíván, obvykle se slibnými výsledky. Lze se domnívat, že tento seznam různých polí sociální práce bude v budoucnosti dále rozšiřován. Všude tam, kde se na straně klientů setkáváme s nedostatečnou mírou schopnosti seberegulace vlastního chování, jistou bezbranností vůči stresu či sníženou schopností empatické pozornosti vůči druhým, což se týká prakticky všech polí př́padové sociální práce, je možné o využití tréninku mindfulness legitimně uvažovat. Je na místě ovšem připomenout i možnosti, které nabízí trénink mindfulness samotným sociálním pracovníkům a pracovnicím. Konkrétní možnosti cvičení mindfulness jako nástroje rozvoje některých osobních a profesních kompetencí byly popsány na stránkách Caritas et veritas (č. 2, rok 2017) Michalem Kaczorem, který uvádí velký počet benefitů, které mohou sociální pracovníci cvičením získat. ${ }^{60}$ Tyty pozitivní účinky cvičení se v praxi projevují zpravidla v posílení schopnosti zvládat pracovní stres a ve schopnosti soustředěného jednání při práci s klienty v klíčových či kritických bodech spolupráce. Stejně tak může být trénink mindfulness užitečný i neformálním pečujícím, které můžeme vnímat jako skupinu obzvlášt ohroženou chronickým stresem až syndromem vyhoření. Publikované výzkumné studie potvrdily, že cvičící jedinci posílili své schopnosti resistence vưči syndromu vyhoření a navíc referovali o zlepšení vztahů k pečovaným osobám. ${ }^{61}$

Výrazný nástup metod využívajících trénink mindfulness v sociální práci nás ovšem musí vést také k jisté opatrnosti při jejich užívání v praxi. Musíme si i přes svůj optimismus zachovat kritický postoj. $\mathrm{V}$ závěru textu byly zmíněny některé sporné či negativní účinky cvičení mindfulness, které se objevují spíše zř́́dka a velmi individuálně, ale přesto je nutno s nimi počítat. V praxi je proto vždy zapotřebí s klienty průběžně reflektovat vlivy cvičení na jejich duševní prožívání. Za prvé musíme počítat $\mathrm{s}$ tím, že trénink mindfulness nemusí mít v konkrétních př́ípadech žádný vliv na klientovy kompetence, kdy bychom měli poté umět flexibilně reagovat nabídkou jiných metod. Za druhé musíme počítat i s tou možností, že trénink mindfulness $\mathrm{v}$ některých př́padech způsobí u klienta výskyt některých nechtěných negativně proživaných duševních stavů. Následně je nutno zvážit, které $\mathrm{z}$ nich se dají terapeuticky zužitkovat, $\mathrm{v}$ ostatních př́padech je vhodné samotné cvičení mindfulness přerušit či ukončit.

Výzkumy využívání tréninku mindfulness v pomáhajících profesích nadále pokračují. Konkretizují aplikační možnosti tohoto cvičení $\mathrm{v}$ praxi, reflektují potenciální rizikové faktory a přináší další popisy vztahu mezi různými procesy v mozku a naším duševním prožíváním. Je pravděpodobné, že v blízké budoucnosti budou vznikat komplexní kursy tréninku mindfulness, specializované

60 Srov. Michal KACZOR, Všímavost (mindfulness) jako potenciální nástroj rozvoje osobnosti sociálního pracovníka, Caritas et veritas 2/2017, s. 40-50.

61 Srov. () Constance L COOGLE - Kirk Warren BROWN - Jessica M. HELLERSTEIN - Allie RUDOLPH, Mindfulness-Based Alzheimer's Caregiving: A Randomized Controlled Trial: Replication Report (on-line), dostupné na: https://vcoa.chp.vcu.edu/media/ college-of-health-professions/virginia-center-on-aging/pdf/center-reports/aoa_reporting.pdf2016, citováno dne 28. 12. 2018; Dharma Singh KHALSA, Stress, Meditation, and Alzheimer's Disease Prevention: Where The Evidence Stands, Journal of Alzheimer's Disease 1/2015, s. 1-12; Ken A. PALLER - Jessica D. CREERY - Susan M. FLORCZAK - Sandra WEINTRAUB - M. Marsel MESULAM - Paul J. REBER - Jessica KIRAGU - Joshua ROOKS - Adam SAFRON - Darby MORHARDT - Mary O'HARA - Kathryn L. GIGLER John M. MOLONY - Michael MASLAR, Benefits of Mindfulness Training for Patients With Progressive Cognitive Decline and Their Caregivers, American Journal of Alzheimer's Disease and Other Dementias 3/2014, s. 257-267. 
př́mo na využívání této metody v sociální práci, a v souvislosti s tím se trénink mindfulness časem stane standardní součástí metod našeho oboru. Mnoho důvodů nás opravňuje říci, že zaslouženě.

\section{Kontakt na autora}

Mgr. Miroslav Kappl, Ph.D.

Univerzita Hradec Králové

Filozofická fakulta, Ústav sociální práce

Víta Nejedlého 573, 50003 Hradec Králové

miroslav.kappl@uhk.cz 